\title{
Autumnal Cultivation of Energetic Plants in Agroecological No-tillage System in Southern Brazil
}

\author{
Vagner Antonio Mazeto ${ }^{1,2}$, Maurício Ursi Ventura ${ }^{3}$, Helder Rodrigues da Silva ${ }^{1}$, Francisco Skora Neto $^{4}$ \\ \& Ricardo Ralisch ${ }^{3}$ \\ ${ }^{1}$ Postgraduate Program in Bioenergy, Universidade Estadual de Londrina, Paraná, Brazil \\ ${ }^{2}$ Unit of São João do Ivaí, Institute EMATER, Paraná, Brazil \\ ${ }^{3}$ Department of Agronomy, Universidade Estadual de Londrina, Paraná, Brazil \\ ${ }^{4}$ Unit of Ponta Grossa, Instituto Agronômico do Paraná, Paraná, Brazil \\ Correspondence: Helder Rodrigues da Silva, Postgraduate Program in Bioenergy, Universidade Estadual de \\ Londrina, Paraná, Brazil. Tel: 55-433-371-5453. E-mail: heldersrodrigues@hotmail.com
}

Received: March 2, $2019 \quad$ Accepted: July 11, $2019 \quad$ Online Published: September 30, 2019

doi:10.5539/jas.v11n16p168 URL: https://doi.org/10.5539/jas.v11n16p168

\begin{abstract}
Cropping energetic plants could provide soil protection, additional incomes to farmers and suppress weed development without loss of food production. It also contributes to the development of no-tillage cultivation in agroecological farming system. Energetic plants such as: sunflower, crambe, canola and safflower were evaluated in no-tillage agroecological farming in autumnal planting, after soybean crop. Higher plant heights were observed in sunflower, flowering [46 days after emergency (dae)] and harvest (108 dae) was first observed in crambe plants. Intermediate earliness was observed in the sunflower (61 and 136 dae, respectively). Biomass was found greater in the sunflower compared to safflower or canola. Intermediate values were obtained for crambe plants. Greater grain and oil yields were found in descending order in sunflower, crambe, canola and cartamo. Despite the drought period occurred during crop development, sunflower and crambe yields were similar or even higher to means, than yields of these same crops in conventional fields in Brazil. Sunflower and crambe were the best options to take part in succession/rotation system after soybean spring/summer crop.
\end{abstract}

Keywords: oleaginous plants, biofuel, organic agriculture

\section{Introduction}

The climate change associated with the rise in greenhouse gas emissions and the concerns about environmental sustainability of population and economic growth, has stimulated the production the biofuels (Guo, Song, \& Buhain, 2015; Morone \& Cottoni, 2016).

However, the deforestation and the usage of arable fields to cultivate energetic crops, previously occupied by food crops would decrease food production and lead to a loss of carbon in forests and soils (Scarlat \& Dallemand, 2011). Production systems are currently impacted by: the growing costs of fossil fuel based inputs; the rapidly changing technologies; the climate change; and the emerging power of consumers in food systems (Francis \& Wezel, 2015).

No-tillage system contributes for agricultural sustainability systems which greatly reduces soil erosion (Lalas, Gortzi, Athanasiadis, E. Dourtoglou, \& V. Dourtoglou, 2012), energetic expenditure (Dos Santos, Tomm, Spera, $\&$ Ávila, 2007) and occurrence of weeds (Gunstone, 1996). Moreover it maintains and improves soil fertility (mostly phosphorus and organic maters levels) (Santos, Tomm, \& Lhamby, 1995) water retention which diminishes yield loses in drought (Dalmago et al., 2009) and it is also an important approach to reduce emissions of carbon dioxide and mitigate effects of atmosphere warming and climatic changes by carbon retention in the soil (Santos et al., 2013). One of the cover crops usage assumptions for weed management is soil coverage through entire year, eliminating fallow periods in which soil in uncovered and weeds develop and produce seeds (Gunstone, 1996; Mata et al., 2010). For this proposal, plants with vigorous vegetative development which cover quickly the space of lines of cultivation are desirable. Therefore, we study the energetic plants sunflower (Helianthus annuus) cv. Catissol, crambe (Crambe abyssinica Hochst.) cv. FMS-Brilhante, canola (Brassicanapus L.) cv. Rivette, and safflower (Carthamustinctorius L.) cv. common (from IAPAR, Londrina) in 
no-tillage agroecological farming in autumnal planting, after soybean crop, evaluating vegetative growth, earliness, mass and grain yield. Oil yields were calculated from grain yield data (Calegari et al, 2010).

\section{Method}

The experiment was settled in a farm in São Pedro do Ivai County, Paraná State (latitude $41^{\circ} 07^{\prime}$ South, Longitude $73^{\circ} 65^{\prime}$ West and altitude $400 \mathrm{~m}$ ). The levels of soil nutrients were characterized by soil samples and presented 5.4, 8.9, 0.0, 4.3, 8.9, 2.8, 0.4, 9.7, 2,1 and 5.3, 7.4, 0.0, 3.7, 8.5, 2.8, 0.3, 3.4, 1.5, 15.2, for $\mathrm{H}, \mathrm{C}, \mathrm{Al}$, $\mathrm{H}+\mathrm{Al}, \mathrm{Ca}, \mathrm{Mg}, \mathrm{K}, \mathrm{P}$, and $\mathrm{S}$ for $0-10$ and $10-20 \mathrm{~cm}$, respectively. Plants were sown after soybean harvest on March 13, 2011. Plots were $7 \times 4 \mathrm{~m}$ with four lines for sunflower and 8 lines for remainder. Lines were spaced $84 \mathrm{~cm}$ with five plants per linear $\mathrm{m}$ for sunflower crop; $42 \mathrm{~cm}$ with 15 crambe plants, $42 \mathrm{~cm}$ with 20 canola plants; $42 \mathrm{~cm}$ with 10 cartamo plants. No pesticide was applied. Organic compound (mixture of poultry litter and vegetable straw from crops) ( 6 ton ha $\left.{ }^{-1}\right)$ was top dressed 20 days after emergency (dae).

Plant height was assessed 45, 60,71, 84, 108, 156 and 178 days after emergency when coverage of space between plants lines was also observed. The four central lines $(6 \mathrm{~m} \mathrm{long})$ were harvest for crambe, canola and cartamo; and the two central lines for sunflower. Biomass and grains yield were assessed and oil yield was estimated (Calegari et al., 2010). Randomized blocks design with four replicates was used. Data were analyzed by ANOVA and means compared by Tukey test $(\mathrm{p}<0.05)$. Climatic data recorded during period of crop implantation and development was obtained from SIMEPAR (Sistema Meteorológico do Paraná).

\section{Results and Discussion}

A drought period of 36 days was observed, from April 15 to May 21. Frost $\left(-2{ }^{\circ} \mathrm{C}\right)$ was recorded in June 27 and 28. Sunflower had higher plant heights in comparison to other plants in all assessments (Table 1). Fast crop plants growth is a desirable trait for weed management in agroecological farming systems due to weed smothering. Although crambe plants were not so height, their branches expanded laterally and, as well as sunflower, they covered space between cultivated lines, 45 dae, while safflower and canola only 75 dae.

Flowering and harvest were first observed in crambe plants, 46 and 108 dae, respectively (Table 1). Intermediate data were observed for sunflower. Early flowering and harvest is a suitable trait for autumnal crops since it allows the harvest of winter crop or cover crops. Historic regional records show reduction of rainfalls as one trait from fall to winter. Added to early cycle autumn season plants, early soybean cultivars could also contribute to this approach. Anticipating fall-season crop sowing would also anticipate plant cycle. This was true for the sunflower crop, in which, the anticipation of 20 days before sowing lead to a cycle reduction of about 20 days (Backes et al., 2008).

Sunflower generated greater biomass when compared to safflower and canola (Table 1). Intermediate values were obtained for crambe plants. Greater grain and oil yields were found in descending order from sunflower, crambe, canola and safflower (Table 1). Although drought occurred during the period of crop development, sunflower yield was greater than the means of Brazilian sunflower crop yields, which is about $1500 \mathrm{~kg} \mathrm{ha}^{-1}$ (Embrapa, 2016). A higher yield (15\%) was recorded, what suggests competitive edge of the crop in agroecological farming system. Crambe crop had yields similar to the means yields of conventional production fields, which varies from 1000 a $1500 \mathrm{~kg} \mathrm{ha}^{-1}$ (Vazquez et al., 2014). In general, organic products reach an increase of $30 \%$ in their prices. Hence, the productivity obtained adding the additive prices may provide satisfactory incomes. The relatively good yields recorded in the experiment, despite the drought occurrence, may be due to greater water conservation. It has been observed in organic field crops, mostly by usage of organic compound (Khanal, 2009) and the no-tillage cultivation system (Dalmago et al., 2009).

Table 1. Days to reach maximum height, onset of flowering and harvest in different energetics crops

\begin{tabular}{lllll}
\hline Treatments & $\begin{array}{l}\text { Days to reach } \\
\text { maximum height }\end{array}$ & $\begin{array}{l}\text { Maximum height } \\
(\mathrm{m})\end{array}$ & $\begin{array}{l}\text { Onset of flowering } \\
\left(\mathrm{dae}^{1}\right)\end{array}$ & $\begin{array}{l}\text { Harvest } \\
\left(\mathrm{dae}^{1}\right)\end{array}$ \\
\hline Sunflower & 108 & 1.80 & 46 & 136 \\
Crambe & 60 & 1.06 & 61 & 108 \\
Canola & 156 & 1.27 & 85 & 179 \\
Safflower & 156 & 1.07 & 85 & 186 \\
\hline
\end{tabular}

Note. ${ }^{1}$ Day after emergency. 
The estimative of percentage of oil in different energetics crops is presented in the Table 2. These results were calculated according to Calegari et al. (2010). The canola crops obtained the maximum oil percentage (51\%), followed by crambe crops (43.1\%), sunflower crops (42.9\%) and safflower crops with (25\%). These results corroborates with the literature, that reported that the content ranges of the crambe seeds culture for oil ranges between 12 to $40 \%$ (Khanal, 2009; Lalas et al., 2012), the oil content for Sunflower was $40 \%$, for canola seeds 41\% (Mata et al., 2010) and for safflower seed it ranged between 30 and 35\% (Gunstone, 1996).

Table 2. Production of the dried mass, grain yields, oil yields and oil percentage, in different energetics crops

\begin{tabular}{lllll}
\hline Treatments & $\begin{array}{l}\text { Dried mass } \\
\left(\mathrm{kg} \mathrm{ha}^{-1}\right)^{1,2}\end{array}$ & $\begin{array}{l}\text { Grain yields } \\
\left(\mathrm{kg} \mathrm{ha}^{-1}\right)^{1,3}\end{array}$ & $\begin{array}{l}\text { Oil yields* } \\
\left(\mathrm{kg} \mathrm{ha}^{-1}\right)^{1,4}\end{array}$ & \% Oil \\
\hline Sunflower & $5.536 \mathrm{a}$ & $1.731,7 \mathrm{a}$ & $744.7 \mathrm{a}$ & 42.9 \\
Crambe & $3.946 \mathrm{ab}$ & $1.309,0 \mathrm{~b}$ & $565.5 \mathrm{~b}$ & 43.1 \\
Canola & $2.433 \mathrm{bc}$ & $654,7 \mathrm{c}$ & $338.0 \mathrm{c}$ & 51.6 \\
Safflower & $1.663 \mathrm{c}$ & $215,7 \mathrm{~d}$ & $53.9 \mathrm{~d}$ & 25.0 \\
\hline
\end{tabular}

Note. ${ }^{*}$ Results were calculated in accordance with Calegari et al. (2010). ${ }^{1}$ Means followed by same letter do not differ by Tukey test $(\mathrm{p}<0.05) .{ }^{2}$ Coefficient of variation $(\mathrm{CV} \%)=21.89,{ }^{3} \mathrm{CV} \%=12.96,{ }^{4} \mathrm{CV} \%=13.36$

From tested plants, sunflower and crambe were the best alternatives for autumnal season crops due to early coverage of space between lines and grain and oil yields. These features provide additional incomes to farmers. The traits of these specific plants are suitable for their inclusion in a succession / rotation system in agroecological no-tillage system. Additional studies could be conducted in the future to confirm their probable positive effects. We presume that adding benefits of no-tillage cultivation and agroecological system could strongly contribute to improve agriculture sustainability. It can also diminish inputs, mostly herbicides, improve soil conservation, and water retention, and even help mitigate global warming (Santos et al., 2013; Mayer et al., 2016; Zomer et al., 2017). Adding the fact that these are energetic plants for biodiesel production what makes this scenario even more favorable. Therefore, this could provide a significant increase of the sustainable production system.

\section{Conclusion}

Crambe and sunflower crops were the best oil plants for the autumnal season period after soybean harvest due to early vegetative development, coverage of spaces between crop lines, grain and oil yields. Sunflower and crambe, cultivated in agroecological system, showed similar or even greater yields than means of these crops in conventional crops in Brazil. These crop plants are alternatives to be included in agroecological no-tillage farming system that would contribute to the agroecosystem sustainability. Due to the fast growing, flowering and harvest, sunflower and crambe could be sown after soybean and before a winter crop or cover crop avoiding the growth of weeds. The energetic oilseeds culture implemented in periods where nothing was cultivated is a viable option for additional income and biofuel production.

\section{References}

Backes, R. J., Souza, A. M., Balbinot Junior, A. A., Gallotti, G. J. M., \& Bavaresco, A. (2008). Desempenho de cultivares de girassol em duas épocas de plantio de safrinha no Planalto Norte Catarinense. Scientia Agrária, 9, 41-48. https://doi.org/10.5380/rsa.v9i1.10131

Calegari, A., Araújo, P. M., Jorge Leme, M. C., Pereira, J. D., \& Silva, L. J. F. (2010). Avaliação de Plantas oleaginosas potenciais no outono/inverno no Paraná. Paper presented at the In Resumos do Seminário Estadual de Agroenergia, Pelotas, RS.

Dalmago, G. A., Bergamaschi, H., Bergonci, J. I., Kruger, C. A. M. B., Comiran, F., \& Heckler, B. M. M. (2009). Retenção e disponibilidade de água às plantas, em solo sob plantio direto e preparo convencional. Revista Brasileira de Engenharia Agrícola e Ambiental, 13, 855-864. https://doi.org/10.1590/S1415-43662009 000700007

Dos Santos, H. P., Tomm, G. O., Spera, S. T., \& Ávila, A. (2007). Efeito de práticas culturais na conversão e no balanço energéticos. Bragantia, 66(2), 299-306. https://doi.org/10.1590/S0006-87052007000200014

EMBRAPA. (2016). Girassol. Empresa Brasileira de Pesquisa Agropecuária Ministério da Agricultura, Pecuária e Abastecimento. Retrieved from https://www.embrapa.br/soja/cultivos/girassol 
Francis, C. A., \& Wezel, A. (2015). Agroecology and Agricultural Change A2. In D. W. James (Ed.), International Encyclopedia of the Social \& Behavioral Sciences (2nd ed.) (pp. 484-487). Oxford: Elsevier. https://doi.org/10.1016/B978-0-08-097086-8.91026-2

Gunstone, F. D. (1996). Fatty Acid and Lipid Chemistry: Springer, US. https://doi.org/10.1007/978-1-46154131-8

Guo, M., Song, W., \& Buhain, J. (2015). Bioenergy and biofuels: History, status, and perspective. Renewable and Sustainable Energy Reviews, 42, 712-725. https://doi.org/10.1016/j.rser.2014.10.013

Khanal, R. C. (2009). Climate change and organic agriculture. The Journal of Agriculture and Environment, 10. https://doi.org/10.3126/aej.v10i0.2136

Lalas, S., Gortzi, O., Athanasiadis, V., Dourtoglou, E., \& Dourtoglou, V. (2012). Full Characterisation of Crambe abyssinica Hochst. Seed Oil. Journal of the American Oil Chemists' Society, 89(12), 2253-2258. https://doi.org/10.1007/s11746-012-2122-y

Mata, T. M., Martins, A. A., \& Caetano, N. S. (2010). Microalgae for biodiesel production and other applications: A review. Renewable and Sustainable Energy Reviews, 14(1), 217-232. https://doi.org/10.1016/ j.rser.2009.07.020

Mayer, A., Hausfather, Z., Jones, A., \& Silver, W. (2016). The potential of land management to decrease global warming from climate change. In P. Morone, \& L. Cottoni (Eds.), 4-Biofuels: Technology, economics, and policy issues Handbook of Biofuels Production (2nd ed., pp. 61-83). Woodhead Publishing. https://doi.org/10.1016/B978-0-08-100455-5.00004-7

Santos, H. P. D., Tomm, G. O., \& Lhamby, J. C. B. (1995). Plantio direto versus convencional: Efeito na fertilidade do solo e no rendimento de grãos de culturas em rotação com cevada. Revista Brasileira de Ciência do Solo, 19, 449-454.

Santos, R. F., Fornasari, C. H., Bassegio, D., De Souza, S. N. M., \& Secco, D. (2013). Optimization of oil extraction from high energetic potential plants performed through drying and solvent extraction methods. African Journal of Biotechnology, 12(48), 6761-6765. https://doi.org/10.5897/AJB2013.12409

Scarlat, N., \& Dallemand, J.-F. (2011). Recent developments of biofuels/bioenergy sustainability certification: A global overview. Energy Policy, 39(3), 1630-1646. https://doi.org/10.1016/j.enpol.2010.12.039

Vazquez, G. H., lazarini, E., camargo, F. P. D., Ferreira, R. B., \& Peres, A. R. (2014). Produtividade, qualidade fisiológica e composição química de sementes de crambe em diferentes doses de fósforo Biosci. J, 30(3), 707-714.

Zomer, R. J., Bossio, D. A., Sommer, R., \& Verchot, L. V. (2017). Global Sequestration Potential of Increased Organic Carbon in Cropland Soils. Scientific Reports, 7(1), 15554. https://doi.org/10.1038/ s41598-017-15794-8

\section{Copyrights}

Copyright for this article is retained by the author(s), with first publication rights granted to the journal.

This is an open-access article distributed under the terms and conditions of the Creative Commons Attribution license (http://creativecommons.org/licenses/by/4.0/). 